\title{
GERAKAN PENDIDIKAN ISLAM KONTEMPORER ORGANISASI NAHDLATUL WATHAN: KONSEP DAN PRAKSIS
}

\author{
Suparman \\ Mahasiswa Program Doktor Pascasarjana UIN Mataram \\ Email: suparman311279@gmail.com
}

\begin{abstract}
Abstrak: Kajian Pendidikan Islam mencakup berbagai topik yang meliputi pemikiran, institusi, aktivitas, kebijakan, sampai pada ragam teori dan praktik atau dimensi konsepsi dan aplikasi. Mengingat bahwa pendidikan Islam telah berlangsung sejak era Rasulullah SAW. serta banyaknya karya tulis ulama' klasik dan eksistensi institusi yang eksis hingga saat ini, maka substansi pendidikan Islam telah layak menjadi sebuah kajian tersendiri, bahkan memiliki teori dan konsep tersendiri pula. Maksudnya, ruang lingkup, konstruksi teoritis, dan aplikasi pendidikan Islam dengan terminologi lain, memenuhi syarat untuk membangun sebuah disiplin ilmu. Nahdlatul Wathan sebagai organisasi kemasyarakatan Islam telah memberikan andil kepada agama, nusa dan bangsa, dalam bidang pendidikan dan perannya membantu pemerintah mencerdaskan bangsa. Kebutuhan serta hajat masyarakat yang semakin besar dalam bidang pendidikan, tampaknya merupakan salah satu pendorong bagi Nahdlatul Wathan untuk berupaya meningkatkan dan mengembangkan diri dalam mengelola pendidikan. Pertumbuhan dan perkembangan pondok pesantren, madrasah, dan sekolah di lingkungan Nahdlatul Wathan terus mengalami peningkatan, baik jumlah dan jenis sekolah dan madrasah, tingkat atau jenjang pendidikannya, maupun kurikulum yang digunakan terutama yang berada di kelompok NWDI dan NBDI.

Kata Kunci: Gerakan Pendidikan Islam, Kontemporer, Nahdlatul Wathan, Konsep dan Praksis.
\end{abstract}

Abstract: The study of Islamic education covers a variety of topics including thoughts, institutions, activities, policies, to various theories and practices or dimensions of conception and application. Given that Islamic education has been going on since the era of the Prophet Muhammad. as well as the many writings of classical scholars and the existence of institutions that exist today, the substance of Islamic education deserves to be a separate study, and even has its own theory and concept. That is, the scope, theoretical construction, and application of Islamic education with other terms, qualify to build a scientific discipline. Nahdlatul Wathan as an Islamic community organization has contributed to religion, the homeland and the nation, in the field of education and its role in helping the government educate the nation. The growing needs and desires of the community in the field of education seem to be one of the impetus for Nahdlatul Wathan to seek to improve and develop themselves in managing education. The growth and development of Islamic boarding schools, madrasas, and schools in the Nahdlatul Wathan environment continues to increase, both in the number and types of schools and madrasas, the level or level of education, as well as the curriculum used, especially those in the NWDI and NBDI groups.

Keywords: Islamic Education Movement, Contemporary, Nahdlatul Wathan, Concept and Practice. 


\section{PENDAHULUAN}

Pendidikan selalu menjadi isu pokok dimana saja manusia berada, karena pendidikanlah yang akan mengantarkan generasi berikutnya mewarisi keutamaankeutamaan kehidupan generasi sebelumnya. Dengan pendidikan manusia akan menjadi manusia yang seutuhnya, yang mampu mengembangkan segenap potensi yang dimilikinya (Wiguna, Aliverman, 2014:14-15).

Sebagai bagian penting dari hidup dan kehidupan manusia, pendidikan melekat erat di sepanjang eksistensi kehidupan manusia itu sendiri. Dengan demikian, idealnya, pendidikan itu mestinya selalu dinamis sejalan dengan perkembangan dan kebutuhan hidup manusia. Di sinilah letak pentingnya pemikiran pendidikan ikut berbicara dan mengatasi berbagai persoalan yang dihadapi. Sedemikian penting arti pendidikan bagi manusia, Imam Barnadib pernah mengatakan bahwa pendidikan merupakan usaha untuk merealisasikan ide-ide dan idealisme tersebut menjadi kenyataan (Usman, 2010:447).

Jenis paling sederhana dari idealisme pendidikan adalah terdiri dari apa yang diyakini seseorang mengenai pendidikan, yaitu merupakan kumpulan prinsip-prinsip yang membimbing tindakan profesional seseorang. Lebih jauh lagi, idealisme pendidikan berkaitan dengan penetapan hakekat dari tujuan pendidikan, alat pendidikan, kemudian menerjemahkan prinsip-prinsip tersebut ke dalam kebijakan untuk diimplementasikan (Ali Khalil Abu al-'Ainain, 1980:61).

Suatu tantangan terbesar bagi institusi pendidikan Islam Indonesia adalah perannya dalam pembentukan sumber daya manusia yang memiliki komposisi intelektual dan spiritual yang seimbang. Konsep pendidikan masa datang adalah keterpaduan antara khazanah keilmuan modern dan khazanah Islam yang bernuansa budaya lokal.

Islam sebagai agama samawi merupakan agama yang paling lantang memberikan perhatian utama dan unik atas pendidikan. Konsep yang paling awal diintroduser secara doktriner-teologis boleh dibilang sarat dengan terma-terma pendidikan, yaitu yang termuat dalam wahyu pertama (H. M. Taufik, 2012:1). Paling tidak tiga kata kunci yang dapat dipandang secara langsung berkaitan dengan terma pendidikan, yaitu membaca (iqra'), mengajar ('allama), satu akar dengan pengetahuan ('ilm) dan pena (qalam). Ketiga konsep tersebut mengimplementasikan muatan belajar, menulis, riset, buku, ilmu pengetahuan, pemahaman spritual serta 
gambaran sifat universal dari semuanya itu.

Untuk mencoba mengatasi persoalan pendidikan di dunia Islam, menurut Hasan Langgulung, telah hadir tiga pola pemikiran :pertama, pola pemikiran pendidikan Islam yang berorientasi kepada pola pendidikan modern di Barat; kedua, pola pemikiran yang berorientasi dan bertujuan untuk memurnikan kembali ajaran Islam; Ketiga, pola pemikiran yang berorientasi pada kekayaan dan sumber daya bangsa masing-masing dan bersifat nasionalisme (Ismail Raji al-Faruqi, 1984:12).

Sejalan dengan upaya kaum muslimin di berbagai belahan dunia Islam, termasuk di Indonesia yang hingga sekarang terus berusaha berbenah diri dalam bidang pendidikan, Nahdlatul Wathan juga sudah cukup lama ikut mengambil bagian memikirkan persoalan pendidikan bagi masyarakat, khususnya di Lombok, Nusa Tenggara Barat. Keikutsertaan dan kepedulian Nahdlatul Wathan dalam memikirkan dan menangani masalah pendidikan yang dihadapi masyarakat Lombok itu tampaknya didorong oleh rasa tanggungjawab dan dihadapkan dengan realitas umat Islam di daerah tersebut masih jauh tertinggal dalam bidang pendidikan.

Kehadiran Nahdlatul Wathan sebagai organisasi sosial keagamaan yang bergerak dalam berbagai bidang, utamanya bidang pendidikan, berawal dari gagasan dan pemikiran Maulanasysyaikh Tuan Guru Kiai Haji Muhammad Zainuddin Abdul Madjid untuk mendirikan Madrasah Nahdlatul Wathan Diniyah Islamiyah, disingkat NWDI, dan Nahdlatul Banat Diniyah Islamiyah, di singkat NBDI, sehingga nama Nahdlatul Wathan sebagai organisasi diambil dari dua kata pertama nama NWDI tersebut.

Keberadaan awal Nahdlatul Wathan dengan dua Madrasahnya itu bermaksud untuk mengubah dan memperbaiki kondisi, prinsip belajar mengajar, dan cara berpikir masyarakat Lombok dalam bidang pendidikan yang sudah cukup lama dipraktekkan, sehingga tidak membawa perubahan kearah kemajuan dan peningkatan mutu pendidikan.

Keberadaan Nahdlatul Wathan sebagai organisasi yang lahir dari Nahdlatul Wathan Diniyah Islamiyah (NWDI) dan Nahdlatul Banat Diniyah Islamiyah (NBDI) yang intinya bergerak di bidang pendidikan telah menetapkan iman dan takwa sebagai nilai dasar pendidikan serta memilih yaqin, ikhlas, dan istiqamah sebagai nilai operasionalnya. Nilai dasar dan nilai operasional tersebut adalah juga merupakan pokok pangkal perjuangan institusi itu sejak lahirnya hingga sekarang. 
Sampai saat ini, Nahdlatul Wathan telah banyak menunjukkan prestasi dan dedikasinya dalam mengemban tugas kemanusiaan tersebut. Banyaknya kader dan alumni Nahdlatul Wathan yang ikut mengambil bagian menyemarakkan suasana pendidikan serta tersebarnya perguruan institusi itu ke seluruh penjuru pulau Lombok, bahkan ke luar kawasan daerah tersebut mengarah kepada kesimpulan seperti itu.

Pendidikan Nahdlatul Wathan banyak dipengaruhi oleh latar belakang pendidikan tokoh utamanya yang cukup lama belajar di Negara Timur Tengah, Saudi Arabia. Walaupun demikian, Nahdlatul Wathan tidak menutup diri terhadap perkembangan dan perubahan yang terjadi di tengah-tengah masyarakat, khususnya bidang pendidikan. Hingga sekarang, organisasi ini telah banyak menunjukkan prestasi dan dedikasinya dalam mengemban tugas kemanusiaan tersebut.

Mencermati paparan diatas, maka ada tiga permasalahan fital yang menjadikan penulis tertarik untuk membahas disiplin ilmu ini, pertama: pendidikan Islam selalu update untuk dikaji baik pendidikan Islam era klasik maupun era modern; kedua: pendidikan Islam Kontemporer sangat menarik untuk dieksplorasi dari sisi kajian konsepsi dan kajian aplikasi; ketiga: pendidikan Islam Kontemporer sangat rentan dengan tantangan dan peluang, sehingga dapat memunculkan beragam temuan sebagai kontribusi positif bagi seluruh umat manusia.

\section{TERMINOLOGI PENDIDIKAN ISLAM KONTEMPORER}

Kajian pendidikan Islam (Bashori Muchsin, 2010:17-18) mencakup berbagai topik yang meliputi pemikiran, institusi, aktivitas, kebijakan, sampai pada ragam teori dan praktik atau dimensi konsepsi dan aplikasi. Mengingat bahwa pendidikan Islam telah berlangsung sejak era Rasulullah SAW. serta banyaknya karya tulis ulama' klasik dan eksistensi institusi yang eksis hingga saat ini, maka substansi pendidikan Islam telah layak menjadi sebuah kajian tersendiri, bahkan memiliki teori dan konsep tersendiri pula. Maksudnya, ruang lingkup, konstruksi teoritis, dan aplikasi pendidikan Islam dengan terminologi lain, memenuhi syarat untuk membangun sebuah disiplin ilmu. Disisi lain, pendidikan Islam merupakan pendidikan yang secara spesifik memiliki ciri Islami, berbeda dengan konsep pendidikan lain yang kajiannya lebih fokus pada pemberdayaan umat berdasarkan al-Qur'an al-Karim dan al-Hadits al-Nabawi. Artinya, kajian pendidikan Islam bukan 
sekedar menyangkut aspek normatif ajaran Islam, tetapi juga aplikasinya dalam ragam materi, institusi, budaya, nilai, dan dampaknya terhadap pemberdayaan umat.

Oleh karena, pemahaman tentang seluruh term dimaksud merupakan integrasi holistik dalam mengembangkan sumber daya manusia yang beriman, berislam, dan berihsan (Sri Minarti, 2013:26). Jadi sangat wajar kalau para pakar atau praktisi dalam memaparkan definisi pendidikan Islam meninggalkan, dan bahkan sangat concern terhadap konstruksi peserta didik sebagai subjek dan objek, karena memang mereka akan selalu terlibat dalam perbincangan konteks pendidikan Islam.

\section{KONTEKS DAN LATAR BELAKANG PENDIRIAN NAHDLATUL WATHAN}

Nahdlatul Wathan merupakan salah satu organisasi sosial keagamaan Islam di Indonesia yang fokus pada bidang pendidikan, sosial, dan dakwah. Organisasi Nahdlatul Wathan didirikan oleh putra asli sasak, yaitu Maulanassyaikh TGKH. Muhammad Zainuddin Abdul Madjid pada tanggal 15 Jumadil Akhir $1372 \mathrm{H}$, bertepatan dengan tanggal 1 Maret $1953 \mathrm{M}$ di Pancor Lombok Timur Nusa Tenggara Barat (Abdul Fattah dkk, 2017:158). Organisasi Nahdlatul Wathan memainkan peran penting dalam proses Islamisasi di Lombok diawal abad XX melalui gerakan Pesantren dan Madrasah yang terbesar ke seluruh kampung yang terdapat di Pulau Lombok. Kata Nahdlatul Wathan, berasal dari bahasa arab Nahdlah, yang berarti kebangkitan, pergerakan atau pembangunan. Sedangkan Wathan yang berarti tanah air atau Negara. Nahdlatul Wathan berarti kebangkitan tanah air, pembangunan Negara atau membangun Negara (Saipul Hamdi, 2014:23).

Istilah Nahdlatul Wathan sendiri pada mulanya mengalami proses diskusi antara Maulanasysyaikh TGKH. Muhammad Zainuddin Abdul Madjid dengan gurunya Maulanasysyaikh Muhammad Hasan al-Masysyat sewaktu Maulanasysyaikh TGKH. Muhammad Zainuddin Abdul Madjid hendak mendirikan Jam'iyyah ia memohon restu gurunya dan meminta pertimbangan nama. Maulanasysyaikh TGKH. Muhammad Zainuddin Abdul Madjid mengajukan nama Nahdlatul Wathan dengan dasar pemikiran background historis masyarakat pulau Lombok dan umumnya di Nusantara pada waktu itu dalam proses perjuangan kemerdekaan. Kondisi keterpurukan inilah yang harus dibangkitkan. 
Organsasi Nahdlatul Wathan (selanjutnya disebut NW) secara embrional berasal dari Madrasah NW Diniyyah Islamiyyah (NWDI) dan Madrasah Nadlatul Banat Diniyyah Islamiyyah (NBDI) didirikan dalam suasana dan kondisi sosio-historis yang heroik, baik dalam konteks penegakan agama Islam maupun kebangsaan. Kelahiran organisasi tersebut sekaligus memberi respon terhadap konteks sosiohistoris masyarakat pada masa itu. Heroisme dalam aspek penegakan agama Islam tercermin dari upaya yang secara simultan diikuti dengan keyakinan dan keikhlasan untuk memperbaiki pemahaman dan cara keberagamaan. Tujuannya jelas, yakni agar nilai-nilai, praktek, dan budaya Islam dapat dihayati dan diamalkan dalam seluruh aspek kehidupan masyarakat. Sedangkan heroisme dalam aspek kebangsaan terefleksikan dari upaya pembebasan masyarakat dari kebodohan dan ketertindasan melalui pendidikan sebagai bekal untuk memperjuangkan kemerdekaan bangsa (Fahrurrozi dkk, 2014:24).

Atas dasar inilah, maka orientasi NW bertumpu pada upaya-upaya untuk memadukan dan mensinergikan antara agama dan negara. Menurut TGKH. Muhammad Zainuddin Abdul Madjid, penyebutan istilah NW mengandung dua makna filosofis sekaligus, yakni membangun negara dan agama. Artinya bahwa agama dan negara diposisikan sama dalam satu tarikan nafas, yakni membangun agama berarti membangun negara, begitu juga sebaliknya.

Kini, usia organisasi Nahdlatul Wathan telah mencapai 84 tahun. Dalam usianya itu, sudah banyak kontribusi yang diberikan NW kepada masyarakat, khususnya di NTB. Sudah banyak lembaga pendidikan yang dikelola oleh organisasi Nahdlatul Wathan. Mulai dari Taman kanak-kanak, pendidikan dasar hingga perguruan tinggi. Jumlah muridnya kini mencapai puluhan ribu orang. Tak hanya di NTB, organisasi yang berpusat di Lombok Timur ini juga menyebar hingga di berbagai propinsi di Indonesia. NW juga ada di Kalimantan, Sulawesi, Sumatera, Riau, Batam, Bali, Jawa Timur, hingga Jakarta.

NW sendiri memiliki tiga bidang pokok sebagai orientasi aktivitas kelembagaannya, yakni pendidikan, sosial dan dakwah, tiga bidang yang secara signifikan menjadi jalur utama NW dalam berkontribusi di tengah-tengah masyarakat. Berjalannya tiga bidang yang teraktualisasi dalam berbagai program dan kelembagaan, telah membangun masyarakat yang bergabung secara total kepada Nahdlatul Wathan dalam klaim diri 'Nahdliyin'. Nahdliyin adalah sebutan bagi komunitas atau masyarakat yang menjadikan NW sebagai 
identitasnya dalam banyak dimensi sosial, dari yang sangat ideologis seperti Islam, hingga yang sangat politis seperti afiliasi partai (Parhanuddin, 2012:124).

Organisasi Nahdlatul Wathan (NW) yang berdiri di Lombok tentu saja berbeda dengn Nahdlatul Wathan yang pernah ada di Surabaya tersebut, meskipun keterkaitan secara emosional-historis-organisatoris dapat dihubungkan dengan posisi pendiri Nahdlatul Wathan Lombok yang memang pernah menjadi bagian dari organisasi Islam Masyumi (Mustanadi, 2019:3).

Nahdlatul Wathan menganut paham aqidah Islam Ahlussunnah wal-Jamaah 'ala mazhabil Imamisy-Syafi'i r.a dan berasaskan Pancasila sesuai dengan tuntutan Undang-undang Nomor 8 Tahun 1985. sedangkan tujuan organisasi Nahdlatul Wathan adalah I'la'i kalimatillah wa 'izzul Islam wal Muslimin dan keselamatan serta kebahagiaan hidup di dunia dan akhirat (Abdul Hayyi, 1449 H/1999 M:50).

Walaupun Organisasi Nahdlatul Wathan adalah Organisasi keagamaan Islam ortodok, akan tetapi Maulanasysyaikh TGKH. Muhammad Zainuddin Abdul Madjid justru menggunakan Pancasila sebagai asas organisasi bukan Islam, ini sangat menarik karena bertolak belakang dari latar belakang keagamaan dan kepartaian politiknya di Masyumi yang dikenal sangat Islami, keputusan ini menunjukkan dirinya sebagai sosok nasionalis-religius yang mengedapankan kepentingan bangsa dari pada kepentingan pribadi dan kelompok, Maulanasysyaikh TGKH. Muhammad Zainuddin Abdul Madjid dikenal sangat koopratif dengan pemerintahan daerah dan pusat.

\section{MAKNA FILOSOFIS NAHDLATUL WATHAN}

Catatan Maulana Syeikh Muhammad Hasan al-Massyath tentang penamaan organisasi yang diusulkan oleh Maulanasysyaikh TGKH. Muhammad Zainuddin Abdul Madjid dengan nama, Nahdlat al-Din al-Islam li al-Wathanatau Nahdlat al-Islam li al-Wathan dapat dijadikan pijakan bahwa relasi antara agama dan negara dalam konteks ini bersifat integral dan simbiosis mutualisme. Artinya, negara sebagai sebuah institusi memerlukan agama sebagai basis moral untuk menegakkan berdirinya suatu institusi negara. Sementara agama tidak akan berfungsi maksimal tanpa ada dukungan dari negara. Jadi agama mengisi preferensi nilai-nilai normatif dari sebuah negara (Fahrurrozi, t.t:3).

Organisasi Nahdlatul Wathan secara embrional berasal dari Maadrasah Nahdlatul Wathan Diniyah Islamiyah (NWDI) dan Madrasah Nahdlatul Banat Diniyah 
Islamiyah (NBDI) didirikan dengan suasana dan kondisi sosio historis, baik dalam konteks penegakan Agama Islam maupun kebangsaan. kelahiran Negara tersebut sekaligus memberi respon terhadap konteks sosio historis masyarakat pada masa itu. Dalam penegakan keagamaan tercermin dari upaya yang secara simultan diikuti dengan keyakinan dan keikhlasan untuk memperbaiki pemahaman dan cara keberagamaan. Tujuannya jelas bahwa agar nilai-nilai, praktet dan budaya Islam dapat dihayati dan diamalkan dalam seluruh aspek kehidupan bermasyarakat. sedangkan dalam aspek kebangsaan terefleksikan dari upaya pembebasan masyarakat dari kebodohan dan ketertindasan melalui pendidikan sebagai bekal untuk memperjuangkan kemerdekaan bangsa.

\section{MAKNA SIMBOL ORGANISASI NAHDLATUL WATHAN}

Simbol organisasi Nahdtaul Wathan adalah bulan bintang yang bersinar lima dengan gambar putih dan warna dasar hijau, simbol Nahdlatul Wathan ini mirip dengan lambang partai politik. Masyumi dan partai Bulan Bintang di era reformasi. Keterlibatan Maulanasysyaikh TGKH. Muhammad Zainuddin Abdul Madjid dalam partai politik Masyumi sangat mempengaruhi konsep pemikiran dalam mengembangkan organisasi Nahdlatul Wathan (Muhammad Noor, 2014:215).

Adapaun arti dan falsafah lambang organisasi Nahdlatul Wathan adalah: 1). Bulan melambangkan Islam, 2). Bintang melambangkan iman dan taqwa, 3). Sinar Lima melambangkan rukun Islam, 4). Warna gambar dan tulisan putih melambangkan Ikhlas dan Istiqomah, 5). Warna dasar hijau melambangkan selamat bahagia dunia dan akhirat (Fahrurrozi, 2019:4).

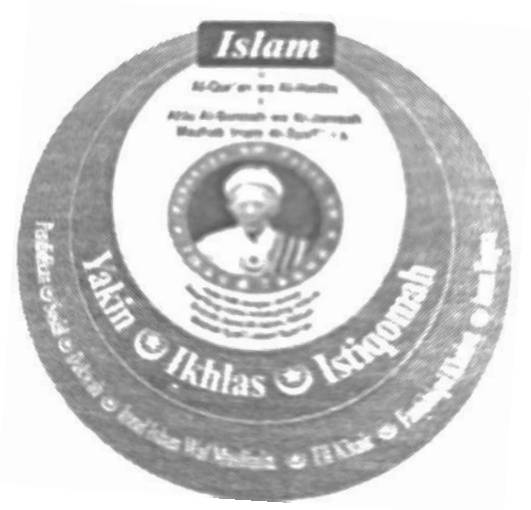

Simbolisasi Lambang di atas, tertera pada lapisan paling dalam adalah pencetus, pendiri Organisasi Nahdlatul Wathan (NW) organisasi terbesar di NTB yang selalu berada dalam denyut jantung pendirinya, seorang Waliyullah Quthub al- 
Aqthab al-Alim al-Allamah al-Arif billah Maulanasysyaikh TGKH. Muhammad Zainuddin Abdul Madjid al-Anfanany al-Masyhur. NW sebagai sebuah pergerakan suci putih bersih untuk menggapai misi besar li i'laai kalimatillah wa 'Izzi al-Islam wa al-Muslimin, menjadikan Islam sebagai pilar keorganisasian yang bernorma pada dua dasar fundamental normatif Islam; al-Qur'an dan al-Hadits dengan berteologikan pada ajaran ahl assunnah wa al-jamaah, sekaligus berkomitmen terhadap mazhab Imam al-Syafi'i dalam legal formal yurisprudensi (syari'ah) dalam bingkai pokoknya NW pokok NW Iman dan Taqwa, melalui spirit dan semangat trilogi perjuangan Yakin, Ikhlas dan Istiqomh dalam menjalankan visi misi utama organisasi NW pada ranah Pendidikan, Sosial, dan Dakwah Islamiah yang dilambari dengan NW Fi alKhair yang berorientasi pada kebaikan dan kesejahteraan di samping menjunjung tinggi semangat optimisme dan semangat kompetisi menuju kesuksesan global (rahmatan li al-Alamin) dan nilai-nilai kebaikan universal (al-Khairat) demi tegaknya Iman dan Taqwa bagi segenap anak bangsa (al-Wathan) yang ber-Pancasila dan ber-UUD 1945.

Bagi Jamaah Nahdlatul Wathan simbol ini tidak hanya menjadi pajangan tetapi juga diamalkan dalam kehidupan sehari-hari melalui lembaga pendidikan formal dan informal seperti Ma'had Dar al-Qur'an wal-Hadits,Madrasah Aliah Keagamaan, serta Perguruan Tinggi di sekitar lingkungan Nahdlatul Wathan penyebaran dan penguatan nilai-nilai keislaman terus dilakukan oleh Maulanasysyaikh TGKH. Muhammad Zainuddin Abdul Madjid selalu menekankan doktrin setiap dakwahnya seperti kompak, utuh bersatu, ikhlas dan istiqamah, serta jargon Nahdlatul wathan juga yang selalu diungkapkan di depan jamaah Nahdlatul Wathan adalah pokoknya NW pokok NW Iman dan Taqwa.

Didalam organisasi Nahdlatul Wathan juga memiliki badan-badan otonom diluar tanggung jawab ketua umum pengurus besar Nahdlatul Wathan. Diantara badanbadan otonom tersebut adalah kelompokMuslimat Nahdlatul Wathan, Pemuda Nahdlatul Wathan, Ikatan Pelajar Nahdlatul Wathan (IPNW), Himpunan Mahasiswa Nahdlatul Wathan (HIMMAH NW), Persatuan Guru Nahdlatul Wathan (PGNW), Ikatan Sarjana Nahdlatul Wathan (ISNW), Ikatan Putri Nahdlatul Wathan (Nahdliyat NW).

Selain badan otonom, terdapat juga lembaga-lembaga di dalam organisasi Nahdlatul Wathan yang berada dibawah tanggungjawab ketua umum Pengurus Besar diantaranya adalah Badan Pengkajian, Penerangan, dan Pengembangan 
Masyarakat Nahdlatul Wathan (BP3MNW), Jam'iyyatul Qurra'wal-Huffaz, Jamaah Hizib Nahdlatul Wathan, Tarekat Hizib, Kelompok Wirid dan Lembaga Bimbingan Ibadah Hajji Nahdaltul Wathan (LBIHNW).

\section{KONSISTENSI NAHDLATUL WATAN UNTUK INDONESIA}

Organisasi kemasyarakatan yang tumbuh dan berkembang di Indonesia eksistensinya diakui oleh konstitusi. Pengakuan tersebut harus tetap dipertahankan oleh setiap organisasi kemasyarakatan dengan mengikuti ketentuan-ketentuan konstitusi dan peraturan perundang-undangan yang berlaku di Negara Kesatuan Republik Indonesia.

Bagi Maulanasysyaikh TGKH. Muhammad Zainuddin Abdul Madjid Islam adalah Agama yang sangat komprehensif dan merakyat bagi kelangsungan hidup manusia secara umum. Islam tidak mengenal kekerasan, kepobian, dan kepanikan secara matia-matian. Tetapi Islam adalah sebuah agama yang mengajarkan kedamaian, kenyamanan, keamanan, dan kebahagiaan. Siapapun mereka dapat menikmat Islam secara terbuka asalkan tidak bermaksud menggerogoti Islam dari dalam secara bersembunyi.

Sebagai agama dakwah Maulanasysyaikh TGKH. Muhammad Zainuddin Abdul Madjid mengerti dengan apa agama ini disebarkan pada masyarakat sasak. Bagaimana cara mensosialisasikannya serta kebijakan apa-apa yang harus diambil dalam rangka memperkuat ketahanan Islam di mata mereka. Berbekal keilmuan di Makkah. Maulanasysyaikh TGKH. Muhammad Zainuddin Abdul Madjid secara bertahap melebur dengan kultur masyarakatnya dengan melakukan beberapa langkah-langkah strategi yang menjadi modal atau mesin penggerak keislamannya (Munawir Husni, 2014:54).

Keuletan dan ketekunan pendiri Nahdlatul Wathan, Maulanasysyaikh TGKH. Muhammad Zainuddin Abdul Madjid serta bantuan seluruh kader Nahdlatul Wathan yang telah tersebar itu, dalam menyampaikan dakwah dan misi Nahdlatul Wathan menjadikan organisasi ini terkenal dan menjadi panutan masyarakat. Eksistensi Nahdlatul Wathan sebagai organisasi, telah diakui keabsahannya oleh pemerintah Republik Indonesia dalam melaksanakan aktivitas organisasi berdasarkan pada:

1. Akte Nomor : 48 Tahun 1957 yang dibuat dan disahkan oleh Notaris Pembantu Hendrik Alexander Malada di Mataram. 
2. Akte Nomor : 50 tanggal 25 Juli 1960 yang disahkan oleh Notaris Pengganti Sie Ik Tiong di Jakarta, dengan pengakuan dan penetapan Menteri Kehakiman pada tanggal 17 Oktober 1960, Nomor : J. A. 5/105/5 dan dimuat dalam Berita Negara Republik Indonesia Nomor : 90 tanggal 8 Nopember 1960.

3. Akte Nomor :31 tanggal 15 Februari 1987 dan Akte Nomor : 32 tanggal 15 Februari 1987 yang dimuat dan disahkan oleh Wakil Notaris Sementara Abdurrahim, $\mathrm{SH}$.

Akta-akta tersebut merupakan landasan hukum organisasi Nahdlatul Wathan dalam melaksanakan aktivitas diseluruh wilayah Negara Kesatuan Republik Indonesia. Dan jika kita lihat dari legalitas Nahdlatul Wathan patut kiranya mengakui bahwa antara azaz Islam, Bangsa dan Nahdlatul Wathan saling berintegrasi dan berkoneksi demi satu tujuan kearah Indonesia yang lebih baik lagi.

Organisasi Nadlatul Wathan sesuai dengan misinya yaitu pendidikan, sosial dan dakwah Islamiyah sudah mengahantarkan Indonesia kedepan pintu germbang kemerdekaan dalam artian merdeka dalam berfikir, bersosial dan bebas untuk menyampaikan dakwah-dakwah Islamiyah yang berlandaskan ajaran Ahlul sunnah waljamaah serta tidak bertentangan dengan UUD dan Pancasila. Dimana dahulu sejak masa penjajahan kita semua tahu bahwa gerakan-gerakan masyarakat Indonesia yang mengarah pada kemerdekaan itu sangat ditentang oleh Kolonial. Namun setelah merdeka Nahdlatul Wathan dan masyarakat Indonesia bersatu saling mengisi demi Negara Indonesia yang lebih baik.

\section{NAHDLATUL WATHAN: GERAKAN PENDIDIKAN ISLAM KONTEMPORER}

Maulanasysyaikh Tuan Guru Kiai Haji Muhammad Zainuddin Abdul Madjid adalah figur sentral di Lombok yang berjasa merekonstruksi dan bahkan mampu mendekonstruksi semangat kebangsaan religius pada masa penjajahan Belanda dan Jepang. la mampu menggelorakan semangat juang masyarakat Lombok melalui lembaga khusus yang didirikannya untuk melawan penjajah dengan menginternalisasikan terlebih dahulu nilai-nilai "Hubb al-Wathan" kepada santrinya melalui pendidikan yang didirikan pertama kali yang diberi nama "al-Mujahidin". Dalam konteks ini, dapat dilihat ide dan semangat kebangsaan religius yang digelorakan kepada masyarakat waktu itu yang mendapat bimbingan langsung dari Maulanasysyaikh Tuan Guru kiai Haji Muhammad Zainuddin Abdul Madjid (Hamzanwadi) (Tuan Guru Bajang L.G.M. Zainuddin Atsani, 2019:53). 
Organisasi kemasyarakatan yang kegiatannya dipusatkan dalam bidang pendidikan, sosial, dan dakwah merupakan patner pemerintah dalam upaya membangun manusia seutuhnya dan membangun seluruh masyarakat Indonesia yang mayoritas beragama Islam dalam rangka mewujudkan tujuan nasional sebagaimana tercantum dalam pembukaan UUD 1945.

Pondok Pesantren adalah lembaga yang bisa dikatakan wujud proses perkembangan sistem pendidikan nasional. Dari segi historis, pesantren tidak hanya identik dengan makna keislaman, tetapi juga mengandung makna keaslian Indonesia, sebab lembaga yang serupa pesantren ini sebenarnya sudah ada sejak pada masa kekuasaan Hindu dan Budha, sehingga Islam tinggal meneruskan dan mengislamkan lembaga pendidikan yang sudah ada. Tentunya ini tidak berarti mengecilkn peranan Islam dalam memelopori pendidikan di Indonesia.

Nahdlatul Wathan sebagai organisasi kemasyarakatan Islam telah memberikan andil kepada agama, nusa dan bangsa, dalam bidang pendidikan dan perannya membantu pemerintah mencerdaskan bangsa. Kebutuhan serta hajat masyarakat yang semakin besar dalam bidang pendidikan, tampaknya merupakan salah satu pendorong bagi Nahdlatul Wathan untuk berupaya meningkatkan dan mengembang diri dalam mengelola pendidikan. Pertumbuhan dan perkembangan pondok pesantren, madrasah, dan sekolah di lingkungan Nahdlatul Wathan terus mengalami peningkatan, baik jumlah dan jenis sekolah dan madrasah, tingkat atau jenjang pendidikannya, maupun kurikulum yang digunakan terutama yang berada di kelompok NWDI dan NBDI di Pancor (Fahrurrozi, 2004:3).

Melalui kedua madrasah (NWDI dan NBDI) ini kemudian secara berahap masyarakat Lombok mulai mengenal pendidikan formal untuk pertama kalinya. Dengan kedua madrasah ini pula pendidikan masyarakat secara tahap demi setahap terus meningkat. Meningkatnya tingkat pendidikan masyarakat secara tidak langsung dapat mendorong terjadinya perubahan sosial masyarakat Lombok (Baharuddin, 2007:115).

Kedua lembaga madrasah tersebut selanjutnya dijuluki "Dwi Tunggal Pantang Mundur", mengalami kemajuan yang sangat pesat, baik dalam perkembangannya dengan berdirinya madrasah-madrasah cabang maupun kelengkapan saranaprasarana pendidikannya. Pesatnya pertumbuhan dan perkembangan cabangcabang NWDI dan NBDI di berbagai tempat di tanah Lombok di atas, maka semakin meningkatnya perkembangan aktivitas sosila lainnya, seperti majlis dakwah, dan 
majlis taklim lainnya.

\section{SIMPULAN}

Pendidikan Islam merupakan pendidikan yang secara spesifik memiliki ciri Islami, berbeda dengan konsep pendidikan lain yang kajiannya lebih fokus pada pemberdayaan umat berdasarkan al-Qur'an al-Karim dan al-Hadits al-Nabawi. Artinya, kajian pendidikan Islam bukan sekedar menyangkut aspek normatif ajaran Islam, tetapi juga aplikasinya dalam ragam materi, institusi, budaya, nilai, dan dampaknya terhadap pemberdayaan umat.

Organisasi Nahdlatul Wathan (selanjutnya disebut NW) secara embrional berasal dari Madrasah NW Diniyyah Islamiyyah (NWDI) dan Madrasah Nadlatul Banat Diniyyah Islamiyyah (NBDI) didirikan dalam suasana dan kondisi sosio-historis yang heroik, baik dalam konteks penegakan agama Islam maupun kebangsaan. Kelahiran organisasi tersebut sekaligus memberi respon terhadap konteks sosiohistoris masyarakat pada masa itu. Heroisme dalam aspek penegakan agama Islam tercermin dari upaya yang secara simultan diikuti dengan keyakinan dan keikhlasan untuk memperbaiki pemahaman dan cara keberagamaan. Tujuannya jelas, yakni agar nilai-nilai, praktek, danbudaya Islam dapat dihayati dan diamalkan dalam seluruh aspek kehidupan masyarakat. Sedangkan heroisme dalam aspek kebangsaan terrefleksikan dari upaya pembebasan masyarakat dari kebodohan dan ketertindasan melalui pendidikan sebagai bekal untuk memperjuangkan kemerdekaan bangsa.

Nahdlatul Wathan menganut paham aqidah Islam Ahlussunnah wal-Jamaah 'ala mazhabil Imamisy-Syafi'i r.a dan berasaskan Pancasila sesuai dengan tuntutan Undang-undang Nomor 8 Tahun 1985. sedangkan tujuan organisasi Nahdlatul Wathan adalah I'la'i kalimatillah wa 'izzul Islam wal Muslimin dan keselamatan serta kebahagiaan hidup di dunia dan akhirat.

Catatan Maulanasysyeikh Muhammad Hasan al-Massyath tentang penamaan organisasi yang diusulkan oleh Maulanasysyaikh TGKH. Muhammad Zainuddin Abdul Madjid dengan nama, Nahdlat al-Din al-Islam li al-Wathanatau Nahdlat al-Islam li al-Wathan dapat dijadikan pijakan bahwa relasi antara agama dan negara dalam konteks ini bersifat integral dan simbiosis mutualisme.

Arti dan falsafah lambang organisasi Nahdlatul Wathan adalah: 1). Bulan melambangkan Islam, 2). Bintang melambangkan iman dan taqwa, 3). Sinar Lima 
melambangkan rukun Islam, 4). Warna gambar dan tulisan putih melambangkan Ikhlas dan Istiqomah, 5). Warna dasar hijau melambangkan selamat bahagia dunia dan akhirat.

Eksistensi Nahdlatul Wathan sebagai organisasi, telah diakui keabsahannya oleh pemerintah Republik Indonesia dalam melaksanakan aktivitas organisasi berdasarkan pada:

1. Akte Nomor : 48 Tahun 1957 yang dibuat dan disahkan oleh Notaris Pembantu Hendrik Alexander Malada di Mataram.

2. Akte Nomor : 50 tanggal 25 Juli 1960 yang disahkan oleh Notaris Pengganti Sie Ik Tiong di Jakarta, dengan pengakuan dan penetapan Menteri Kehakiman pada tanggal 17 Oktober 1960, Nomor : J. A. 5/105/5 dan dimuat dalam Berita Negara Republik Indonesia Nomor : 90 tanggal 8 Nopember 1960.

3. Akte Nomor :31 tanggal 15 Februari 1987 dan Akte Nomor : 32 tanggal 15 Februari 1987 yang dimuat dan disahkan oleh Wakil Notaris Sementara Abdurrahim, $\mathrm{SH}$.

Maulanasysyaikh Tuan Guru Kia Haji Muhammad Zainuddin Abdul Madjid adalah figur sentral di Lombok yang berjasa merekonstruksi dan bahkan mampu mendekonstruksi semangat kebangsaan religius pada masa penjajahan Belanda dan Jepang. la mampu menggelorakan semangat juang masyarakat Lombok melalui lembaga khusus yang didirikannya untuk melawan penjajah dengan menginternalisasikan terlebih dahulu nilai-nilai "Hubb al-Wathan" kepada santrinya melalui pendidikan yang didirikan pertama kali yang diberi nama "al-Mujahidin". Dalam konteks ini, dapat dilihat ide dan semangat kebangsaan religius yang digelorakan kepada masyarakat waktu itu yang mendapat bimbingan langsung dari Maulanasysyaikh Tuan Guru Kiai Haji Muhammad Zainuddin Abdul Madjid (Hamzanwadi).

Nahdlatul Wathan sebagai organisasi kemasyarakatan Islam telah memberikan andil kepada agama, nusa dan bangsa, dalam bidang pendidikan dan perannya membantu pemerintah mencerdaskan bangsa. Kebutuhan serta hajat masyarakat yang semakin besar dalam bidang pendidikan, tampaknya merupakan salah satu pendorong bagi Nahdlatul Wathan untuk berupaya meningkatkan dan mengembangkan diri dalam mengelola pendidikan. 


\section{DAFTAR PUSTAKA}

Abdul Fattah dkk, Dari Nahdlatul Wathan Untuk Indonesia: Perjuangan TGKH.Muhammad Zainuddin Abdul Madjid (1908-1997). Dinas Sosial NTB, 2017.

Abdul Hayyi, Maulanasysyaikh TGKH. Muhammad Zainuddin Abdul Madjid: Riwayat Hidup dan Perjuangannya. Mataram: Pengurus Besar Nahdlatul Wathan, $1419 \mathrm{H} / 1999 \mathrm{M}$.

Ali Khalil Abu al-'Ainain, Falsafah al-Tarbiyah al-Islamiyyah fi al-Qur'an al-Karîm. Kairo: Dar alFikr al-'Arabiy, 1980.

Baharuddin, Nahdlatul Wathan dan Perubahan Sosial. Yogyakarta: Genta Press, 2007.

Bashori Muchsin, Pendidikan Islam Humanistik: Alternatif Pendidikan Pembebasan Anak. Bandung: Refika Aditama, 2010.

Fahrurrozi dkk, Nahdlatul Wathan dan Pembangunan Sosial-Keagamaan di Nusa Tenggara Barat. Jakarta: Jurnal Bimas Islam Vol. 7 no. 1, 2014.

, Islam Nusantara: Menemukenali Peran Organisasi Nahdlatul Wathan

Terhadap Pembangunan Sosial-Keagamaan di Indonesia Mataram:

Makalah untuk AICIS,t.t.

, Nahdlatul Wathan: Refleksi Keislaman, Kebangsaan, dan Keummatan.

Mataram: CV. Al-Haramain Lombok, 2019.

, Eksistensi Pondok Pesantren di Lombok NTB: Studi Tentang Peranan

Pondok Pesantren Nahdlatul Wathan dalam bidang Pendidikan, Sosial dan Dakwah. Jakarta: PPs UIN Jakarta, 2004.

H. M. Taufik, Kreativitas: Jalan Baru Pendidikan Islam. Mataram: LEPPIM IAIN

Mataram, 2012.

Ismail Raji al-Faruqi, Islamisasi Ilmu Pengetahuan. Bandung: Pustaka, 1984.

Muhammad Noor, Visi Kebangsaan Religius, Refleksi Pemikiran dan Perjuangan

Tuan Guru Kyai Haji Muhammad Zainuddin Abdul Madjid. Jakarta: Logos Wacana IImu, 2014.

Munawir Husni, Nalar Islam Keindoneiaan: Peta Pembahasan Keislaman. Pancor: Multi Persero, 2014.

Mustanadi, Reformasi Pendidikan Islam Lokal: Nahdlatul Wathan. Mataram: Makalah Pendidikan Agama Islam Program Doktor UIN Mataram, 2019. 
Parhanuddin, Nahdlatul Wathan dan Masyarakat Sipil. In Right: Jurnal Agama dan Hak Asasi Manusia Vol. 2, No. I, 2012.

Saipul Hamdi, Nahdlatul Wathan Di Era Reformasi; Agama, Konflik Komunal dan Peta Rekonsiliasi. KKS Yogyakarta: Nawa Institute, 2014.

Sri Minarti, IImu Pendidikan Islam: Fakta Teoritis-Filosofis dan Aplikatif-Normatif. Jakarta: Amzah, 2013.

Tuan Guru Bajang L.G.M. Zainuddin Atsani, Kontruksi Nasionalisme Religius: Narasi Cinta Kebangsaan Religius dalam Karya Sastra Maulana al-Syaikh Tuan Guru Kiai Haji Muhammad Zainuddin Abdul Madjid. Jurnal Al-Amin: Kajin Pendidikan dan Sosial Kemasyarakatan, Volume 4/Nomor 2/Juli-Desember, 2019.

Usman, Pemikiran Pendidikan Nahdlatul Wathan di Lombok. Jurnal Penelitian Keilslaman, Vol. 06, No. 2, Juni 2010.

Wiguna, Aliverman, Isu-Isu Kontemporer Pendidikan Islam.Yogyakarta: Deepublish, 2014. 